\title{
Book Review: Writing About Learning and Teaching in Higher Education: Creating and Contributing to Scholarly Conversations Across a Range of Genres
}

\author{
Kaur Amrita* \\ School of Psychology, College of Liberal Arts, Wenzhou-Kean University, Wenzhou, China
}

Keywords: identity, teaching and learning, higher education, vicarious learning, writing

\section{A Book Review on}

Writing about Learning and Teaching in Higher Education: Creating and Contributing to Scholarly Conversations across a Range of Genres

Mick Healey, Kelly Matthews, and Alison Cook-Sather (United States: Center for Engaged Learning Open-Access Books, Elon University, ), 2020, 403 pages,ISBN: 978-1-951414-04-7

\section{SUMMARY OF THE BOOK}

This book is unique and distinct in more than one way when compared to other texts that guide academic writing in a straightforward and mechanical manner.

The book offers a vicarious learning approach for faculty, staff, and students new to and experienced in writing about learning and teaching. It encompasses lived experiences of seasoned and new academics, graduate students, and undergraduates from different parts of the world, which serves as an informational as well as a motivational source for its audiences in forging their identities as authors.

The content of this book develops systematically in a scholarly yet personal way and inspires readers to be reflective and introspective as part of developing as authors. This approach not only adds meaning to the purpose of writing but provides directions to authors to develop their identities by adopting conscious practices towards writing about teaching and learning in multiple genres. The contemplative and systematic approach presented through the book chapters in six parts opens new ways of thinking about teaching and learning by invoking reflection, engaging in existing conversations, and creating your own dialogue. The book proposes that "writing is a subjective and complex human experience through which people bring diverse perspectives to bear on the practice of learning and teaching" (p.330) and forge their professional identities.

Received: 05 January 2021 Accepted: 08 February 2021

Published: 22 March 2021

\section{EVALUATION OF THE BOOK'S CONTENT: CONTENT AND STYLE}

The book is set against the background of diverse human perspectives and their value and contribution to the dialogue about teaching and learning. Thus, in part one of the book, the authors begin by sharing their positionalities in terms of who they are as "people, scholars, and writers" (p.10). Their personalized introduction sets the stage for readers to pause and locate their own positionalities as 
scholars and in what ways they would like to embrace thinking and writing about teaching and learning. The most significant section of this part of the text is the authors' self-reflection on writing this book, which can be instrumental for many readers own writing.

By considering writing about teaching and learning as a tool for self-learning, self-discovery, and transformation to forge their identities, part two of the book stimulates writers in an intellectual as well as emotional sense about their scholarly work and about to whom and how would they like to communicate. A list of questions, for example, How do you see yourself starting or continuing to engage in scholarly conversations about learning and teaching in higher education across a wide range of genres? (p.21) come across as extremely valuable. The introspective approach helps authors clarify their values and forge identities as writers-an important element that guides powerful written communication and sets it apart from the mechanical writing process.

To continue the process of introspection and preparation to engage in the dialogue, part three of the book explains the underlying motivational process for writing about teaching and learning, which essentially emanates from the identity of being a writers and it prepares readers to think about the precursors of writing by seeking answers to questions such as: What is the motivation behind your writing? What are your preferred outlets for publication? Would you work alone or in collaboration? (p.51). Readings from this section lay a solid foundation for the authors and pave a way to move forward. The final section of this part is unique and rare in similar types of publication. It discusses important criteria for choosing an appropriate outlet in alignment with technical, motivational, and personal preferences of authors by providing authentic information about a variety of journals of teaching and learning.

Acknowledging the diversity of conversation in teaching and learning i.e. multiple disciplines and forms and their contribution in developing our professional identities, part four of the book offer insights on writing for eleven different genres. These genres range from conventional writing, such as empirical, theoretical, and conceptual articles, to non-traditional forms of writing comprising stories, social media, and applications for teaching fellowships, and awards to inspires academics to think in unusual and innovative ways about writing and joining in the dialogue about teaching and learning in higher education. The salient elements of the writing genres are discussed in an active and animated fashion, and the inclusion of reflections from a wide range of scholars is not only informative but also motivational.

Part five provides practical and meaningful advice on priming for writing activities. This section also adopts an animated

\section{REFERENCES}

Friesen, M. D., and Besley, S. C. (2013). Teacher identity development in the first year of teacher education: a developmental and social psychological perspective. Teach. Teach. Edu. 36, 23-32. doi:10.1016/j.tate.2013.06.005

Healey, M., Matthews, K., and Cook-Sather, A. (2020). Writing about learning and teaching in higher education: creating and contributing to scholarly conversations across a range of genre. United States: Center for Engaged Learning Open-Access Books, Elon University, 403. Available at: https:// www.centerforengagedlearning.org/books/writing-about-learning/ approach to communicate with readers by asking introspective questions to guide their writing. The discussion ranges from simple topics like when and where to write to more complex topics like how to assert your voice and seek critical feedback to enhance output. Finally, the Part six focuses on making writing public and participating in scholarly conversations on learning and teaching. Besides regular advise on choosing an outlet and submitting a manuscript, the section discusses strategies for revising the manuscript and, more importantly, promoting the published work in effective ways.

\section{DISCUSSION OF THE BOOK'S CONTENT IN LIGHT OF THE CURRENT NEEDS OF THE COMMUNITY: MERIT}

The book offers merit in two powerful ways. One, it inspires readers and offers them the courage to expand their scholarly horizons by adopting new and unconventional ways of writing and communicating about teaching and learning in higher education. The traditional ways of studying pedagogy and andragogy are grounded in a unidimensional and highly structured empirical approach. To advance the understanding of teaching and learning, it is imperative to include diverse perspectives by listening to multiple voices as they share their subjective experiences of human learning and its underlying processes.

Two, the reflective and introspective approach offered in this book suggests that writing for teaching and learning that integrates personal values and practical approaches can be a potential tool for practitioners to forge identities for themselves by engaging in dialogue with self and others. Research has established that professional identity of teachers is well developed among those who have gained a greater sense of self-knowledge through exploration of their values and beliefs (Friesen and Besley, 2013).

The book, along with its online resources gets too lenghty which may prompt readers to skip some sections. Nevertheless, it is a valuable resource for anyone interested in teaching and learning about higher education.

\section{AUTHOR CONTRIBUTIONS}

The author confirms being the sole contributor of this work and has approved it for publication.

Conflict of Interest: The author declares that the work was conducted in the absence of any commercial or financial relationships that could be construed as a potential conflict of interest.

Copyright (C) 2021 Amrita. This is an open-access article distributed under the terms of the Creative Commons Attribution License (CC BY). The use, distribution or reproduction in other forums is permitted, provided the original author(s) and the copyright owner(s) are credited and that the original publication in this journal is cited, in accordance with accepted academic practice. No use, distribution or reproduction is permitted which does not comply with these terms. 